\title{
The Life, Work and Legacy of Ernest A. Lynton (1926-1998)
}

\author{
Elaine Ward with Emiley Dionne, Emily Wall and Shannon Zelek
}

\section{Introduction}

I will stop here for the moment. It has been a story good to live, fun to write down, and I hope, interesting to read. (Ernest Lynton, 1996c)

Learning about Ernest Lynton's rich life has been interesting for me to uncover. Where many of us only know Ernest through his writings, I have come to learn the origins of the motivations for his work and commitments to advancing the public purpose of higher education and the scholarship of engagement.

The significance of the title of the Metropolitan Universities journal's first issue in 1990, Identity and Culture, is not lost on me as I seek to understand more fully the life, lived experiences, and identity of Ernest A. Lynton that moved him to influence cultural shifts within higher education toward increased value and legitimatization of useful, publicly engaged work. As a researcher, I strive to understand our individual and collective motivations for our community engagement scholarly work. What are our aspirations for this work and its broader impact in society? Why do what we do and how can what we do influence the greater public good. As a steward of change (Ward \& Miller, 2106), I seek ways to use our individual and collective understandings to lift up and advance institutional commitments to civic and community engagement as we help our higher education institutions hold fast to and more fully realize their responsibilities to individuals and communities beyond our walls.

For me, Ernest Lynton was one of the first thought leaders that pushed me to focus my own research on not only the individual work of faculty, their identities and motivations for this work, but also the institutional contexts and cultures that supported or inhibited their publicly useful scholarly work. That institutions of higher education, especially Metropolitan Universities, have a special obligation to their region and while they must:

[Retain] their central purpose and focus if they are to remain the principal societal mechanism for the objective criticism of prevailing views and practices. But metropolitan universities recognize that they must change the way in which this knowledge-centered mission is pursued. The nature, uses, and clientele for knowledge are evolving; the effective interpretation and dissemination of knowledge have become as important as its creation, and an ever more diverse clientele needs [diverse responses]. The form must adapt as the function changes. (Lynton, 1990, p. 4).

A faculty member's work supports the institutional mission and is central to its function. And in "metropolitan universities, members of the faculty bear the principal burden of institutional change, having to adapt and expand their scholarly and pedagogical skills to meet a diversity of challenges for which their traditional training has not prepared them" (Lynton, 1990, p. 5). Just as faculty members have a professional responsibility to advance the institutional mission, so too 
does the institution have a responsibility to support faculty success through the development of policies and infrastructures that recognize and reward what Ernest then called 'professional service' or what we now know as publicly engaged scholarly work (Post, Ward, Long \& Saltmarsh, 2016). Ten years ago, Ernest's work lay the groundwork for my own. For a decade, through my work with the Ernest A. Lynton Award for the Scholarship of Engagement for Early Career Faculty, I have continued to learn from the next generation of publicly engaged scholars and institutional change agents who seek to realize their individual and their institution's public 'obligations to the regions' (Lynton, 1990).

Prior to my research for this special issue, I had no idea Ernest Lynton was an immigrant. His 1998 obituary in the New York Times, summarized his life's work:

Professor Lynton advocated closer cooperation between students and employers based on a system in Germany, where he was born, and he called for apprenticeship programs that would give high school students three years of combined school and work experience. He also urged emphasis on the practical applications of research by faculty members, and he promoted outreach work by them.

—New York Times, April 5, 1998, p. 40

I had researched Ernest's work and scholarly contributions to the field of higher education transformation and community engaged research from the early 90s, but knew little about his previous life. As a narrative methodologist, I wanted to learn more about the man himself, behind the scholarship, experiences and commitments to institutional change. Through this special issue and conversations with some of his closest colleagues and mentees, we will share his story - the man behind the scholarship and higher education transformation. This special issue will deepen our understanding Ernest's own narrative, his contributions, and in turn the impact of the award through the next generation of stewards of institutional change, our posttenure Lynton Award recipients.

Ernest's colleagues and mentees Cathy Burack, Deb Hirsch, Barbara Holland, KerryAnn O'Meara, Lorilee Sandmann and Zelda (Zee) Gamson, Gene Rice and Richard Freeland shared their experiences working with Ernest with me. For them, Ernest was indeed a man of influence and intellectual acumen, and more importantly, he was caring, generous, collaborative, nurturing, and trusting in how he worked with others. The way he worked with others helped these women feel that they were "part of something bigger", that they "mattered" (Driscoll, personal communication), and that their contributions were as valuable as were his own. The strength of their personal connections with Ernest, and his impact on them, were personally and professionally invaluable. I wanted to get to know the man behind the scholarship and learn more about him than they could share with me.

This curiosity led me, and my graduate student research team, to explore institutional archives, genealogy records, and family member memoirs. Working on this issue has led me on a journey of discovery into Ernest's individual work and life as well as the collective experiences of many who worked closely with him to advance higher education's commitment to public purpose, particularly the recognition and reward through promotion and tenure of individual faculty scholarly work. 


\section{Ernst Albracht Loewenstein became Ernest A. Lynton}

Ernest Albert Lynton was born on July 17, 1926 in Charlottenburg, West Berlin, Germany. Charlottenburg was one of two districts with the highest Jewish population in 1920s Berlin, an international, sophisticated and culturally rich area in comparison to other areas of the region (Charlottenburg Wilmersdorf www.berlin.de). He came from a lineage of educated, cosmopolitan family members (Lynton, M. 1995; Hoffman, n.d.). I would not have discovered this without his brother Mark's memoir, Accidental Journey.

"It is him", I said aloud as I realized I was reading Ernest's brother Mark's memoir. He had signed his forward, 'Mark Lynton, Larchmont New York 1994.' I could reference that with a genealogical 'family sheet' that identified Larchmont as the place of Mark's death in 1997 (Hoffman, n.d.). I was certain this was Ernest's brother. Questions I had about Ernest's early childhood years, and how that may have influenced who he was as a scholar, mentor, and institutional change agent, were no longer a gap in his narrative.

To begin with, Ernest's brother begins his memoir with "I was born Max-Otto Ludwig Loewenstein, in Stuttgart, Germany." (p. 3) I now understood why I was having such a hard time finding information on any Lynton family. Mark goes on to verify the genealogy: "both sides of my family had in or near Stuttgart for ten generations or more--a documented fact--and claimed earlier antecedents from Jews who had fled the Spanish Inquisition, which, if not necessarily fiction, remains unverified." (p.3) Mark's narrative not only confirmed everything I had read in Rolf Hoffman's Family Sheet on the Loewenstein family. Hoffman's data came to life in Mark's retelling. I began to understand the socio-political structures of Germany in this period when I further explored the places where Ernest's ancestors had lived. Ernest's great-great-grandparents go back to 1769 in Oetteingen and Steinbach near Schwaebisch Hall. Steinbach is in the thenKingdom of Württemberg (1805-1918) whose capital was Stuttgart. We know from Mark's memoir that he was born in Stuttgart before his parents moved to Berlin.

Ernest's parents were Arthur Jakob Loewenstein (1889-1962) and Martha Luise (Lizzie) Kiefe (6.28.1895 - 1984). Arthur was a banker and later an executive in a German car manufacturing company. Sometime before 1914, he spent time in London to learn about banking. He later authored a book on Jewish banking. Arthur had earned degrees in Law and Economics from Heidelberg University. Ernest's mother Lizzie went to finishing school in France.

Ernest had two uncles and an aunt on his father's side. Gustav (1890-1939) also studied in Heidelberg University. Ernest's uncle Max (1896-1917) died as a young man in France in combat during WWI. Ernest's aunt Else born in 1893 died in Stuttgart in 1930. Both Ernest's father and his uncle Gustav immigrated to the United States, Arthur to New York and Gustav to Los Angeles. Ernest's paternal grandparents were Naphtali Loewenstein of Oedhiem (18521923) and Emilie Wormser (1863-1924). Ernest's paternal grandfather Naphtali founded Pflaum \& Loewenstein Bank around 1880 with his partner, David Pflaum, at Koenig Strasse 31 A in Stuttgart. When David died, Naphtali worked with one of his brothers (he had eight siblings) and they formed the Gebrueder Loewenstein Bank in Stuttgart. 
Ernest's great grandfather, Jakob Loewenstein (Naphtali's dad), was born in Bonfeld on December 26, 1819. Jakob was a teacher and hazzan (a musician who led the congregation in songful prayer) in Gerabronn, Korb, Oedheim, Hohebach, Oberdorf, Sontheim and finally Heilbronn (Hoffman, n.d.). Jakob's father, Loew Lippman Loewenstein (1769-1850), Ernest's great, great, grandfather, was also a teacher. He taught in Steinback near Schwaebisch Hall. This community suffered terribly during Kristallnacht, some 170 years after Leow's birth. Ernest's great, great grandmother Ester's family were also teachers, in Oettingen. As we can see, Ernest descended from a strong lineage of educators.

Mark's retelling of his family origins and accomplishments brings to life the lineage that deepened my connection to their lived experiences.

Moving to Stuttgart in the early 1800s, they evolved from a succession of rabbis and moneylenders to repeated generations of lawyers and bankers, a logical progression. Much of the same thing happened to my mother's family, the Kiefes, who, for a number of generations, lived in Baissingen - a small hamlet southeast of Stuttgart - as the local kuffen (barrel makers), which led to the family name. They, too, discovered banking as a more promising profession and moved to Stuttgart. My grandparents were enthusiastic supporters of the king of Württemberg, his overlord, the emperor of Germany, of all things German; both my father and uncle won Iron Crosses in World War I, and my other uncle was killed in it as an eighteen-year-old volunteer recruit. My father, with both Law and Economics degrees from Heidelberg University, had spent some years in London before 1914 to learn to be a banker. My mother had attended finishing school in England, having been brought up bilingually in French and German. (The same Swiss governess responsible for this remained with the family for almost seventy years, so that my brother [Ernest] and I were equally at ease in both languages.) (p. 3)

I had wondered how Ernest managed in the U.S. education system as an immigrant. I too came to the United States with my parents, a little younger at thirteen and not fleeing persecution.

However, my working-class family background left me without the intellectual or cultural capital to navigate easily the education system here. I had wrongly identified my own immigrant's educational experience with that of Ernest. I had truly marveled at how he managed the transition, and earned his doctorate a short ten years after his arrival. That he accomplished this so quickly, under such circumstances, when English was not even his first language, was amazing to me. It took me that long to earn a bachelor's degree. Gaining insight into his deep intellectual heritage helped me see what Lorilee Sandmann meant when she described Ernest as "a man of small stature, but mammoth intellect" (Sandmann, personal communication.) Ernest's early background, prior to the rise of Nazis, laid the foundation for his success within U.S. higher education.

My research also leads me to believe that his cumulative early experiences led him to advocate for, and strategically advance, the changes he envisioned. He completely understood that the "fundamental mission [of universities was] the disinterested pursuit and promulgation of knowledge... [yet maintaining] the objective criticism of prevailing views and practices" (Lynton, 1990, p. 4). Yet he also knew that the academy still needed to realize itself more fully as a steward of place (CUMU website) and advance its public purpose. 
Mark's account of his own childhood gives us further insight into Ernest's early years:

My father was named head of a major German car manufacturer in 1922, when I was two years old, and we moved to Berlin, where my brother was born some years later. I had a very warm, happy, affluent and sheltered childhood, and I have equally happy memories of my high school years, which began in 1929 at the Franzoesisches Gymnasium. The school had been founded in the 1640s by and for immigrant French Huguenots, and was unusual in continuing to teach all subjects in French; it thus tended to attract a varied and mostly international body of pupils. Subsequent events led to my being exposed to school systems in three different countries, I still believe the German system to have been the most balanced and well rounded. (p. 4)

Ernest's mother had gone to finishing school in France. His father had spent time in England "learning about banking" and the family had the same governess for generations (70 years). Ernest's father was highly accomplished, he had received his doctorate from Heidelberg University, had degrees in law and economics, hand written his dissertation/book on banking, was a banker and now a high level executive in a prominent German car manufacturing company, all the while having a medal of honor from World War I.

His father's career brought them to Berlin in 1922. Mark, then Max, went to France to continue his schooling in 1933. Throughout Ernest's earliest years, life in Germany was overtaken by extreme nationalism and the perceived superiority of a German, Aryan race, an ideology advanced by the Nationalist Socialist German Workers' (Nazi) Party. Three years before Ernest's birth, Adolf Hitler had attempted to seize power from the German government. The failed 1923 coup resulted in his imprisonment, which in turn only led to his increased popularity. When Ernest was just three years old, the severe depression of 1929 paved the way for the rise of Nazi power in Germany. Hitler pronounced that all of the nation's problems would resolve if communists and Jews were driven from Germany (www.speigel.de).

Ernest was just seven years old when Hitler and the Nazi party rose to power in 1933. The rate of erosion of Jewish rights accelerated and two years later, when Ernest was nine, the Nuremberg Laws took all citizenship rights away from Jewish Germans and prevented marriage between Jews and Germans all in the name of protecting German blood and honor. Ernest was ten years of age in 1936, when Jewish rights were further eroded and Jews were not allowed to vote. When he was just 12, in 1938, what can be considered the beginning of the Holocaust took place on November 9 and 10 when Jewish businesses were destroyed and Jews were openly attacked and murdered on the streets across the nation. Kristallnacht (Night of Broken Glass) stands as the event that marked the shift in German policy against the Jews from enslavement to annihilation (www.jewishvirtuallibrary.org). By 1939, all Jews had to carry an identification card with them at all times. Soon, life deteriorated to the point where Jews not only were banned from most public places in Germany, but also were being moved into concentration and forced labor camps. The abominable denial of rights and property, segregation, and "relocation" ultimately led to the systematic mass killing of six million European Jews. Ernest's family left Berlin for Amsterdam in 1935, the same year Hitler's Nuremburg Laws stripped rights and citizenship from the Jewish population. 
Ernest and his parents moved from Berlin to Amsterdam in 1935. They arrived in the United States in 1941, just one year before the Nazi's formulated their 'Final Solution to the Jewish problem', a plan for the liquidation of all European Jews (www.history.com). The family sailed from Lisbon, Portugal to Ellis Island, New York on the steamship Mouzinho. The ship's manifests lists Ernst Albracht (Israel) Loewenstein (UNDER 16).

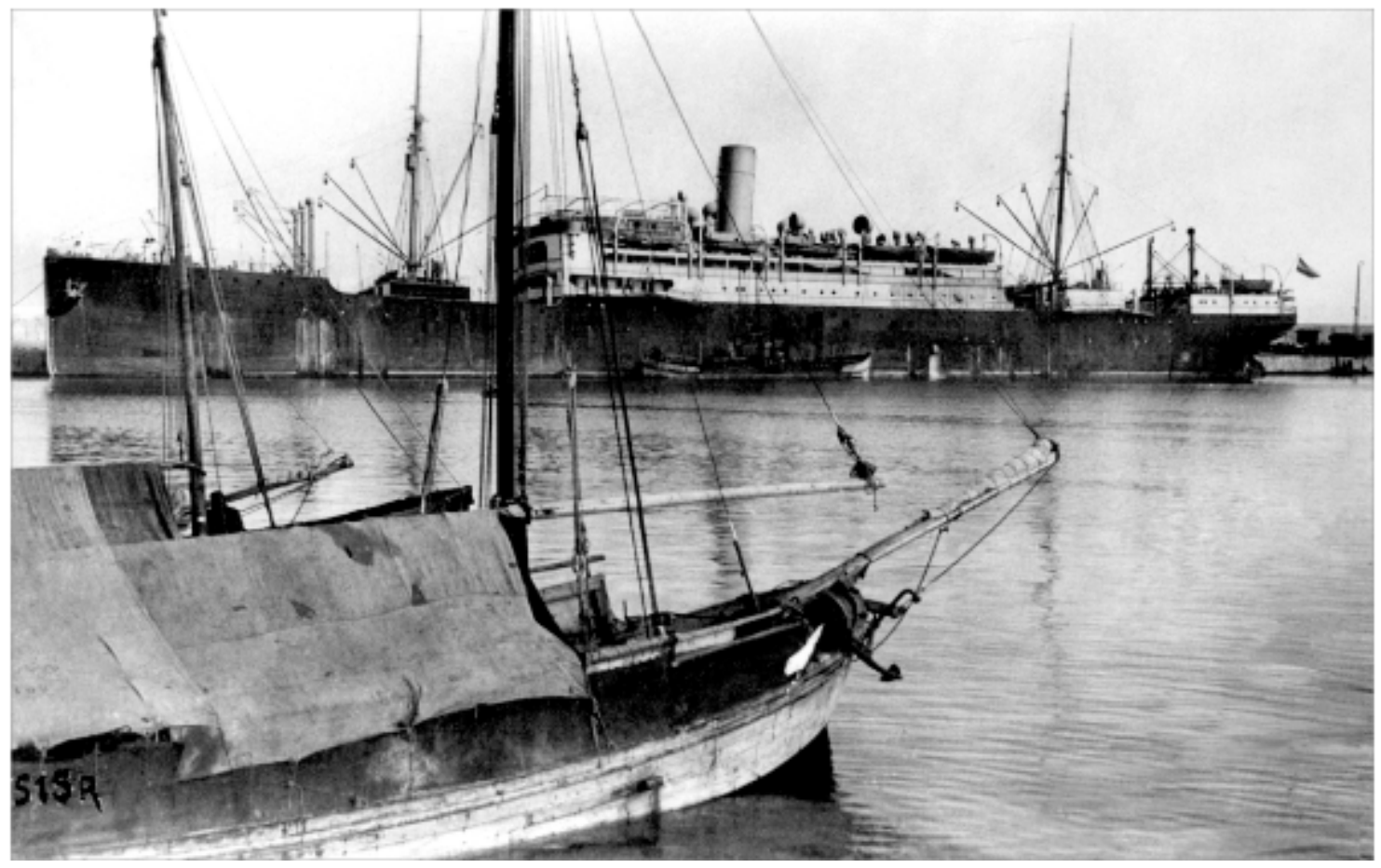

Figure 1. The steamship Mouzinho departing Lisbon for Ellis Island.

The Ellis Island Ledger lists Arthur Loewenstein, passenger number 901763153084, and Martha Lowenstein, passenger number 9011982070101 . Arthur was described as five feet, five inches tall, with fair complexion and blond hair and Martha was the same height with fair complexion and gray hair and grey eyes. Ernest had fair complexion, black hair and brown eyes and was five feet, six inches tall when he arrived at Ellis Island on September 2, 1941. There were 1,650 passengers on the steam ship. The Loewenstein family had obtained their visas in Rotterdam, Holland on May 19, 1941. Ernst's parents listed English and German as their spoken languages and Ernst, French and German.

Mark writes that he "had not seen my family since the summer of 1939 [for seven years], and while in touch since 1941, correspondence had been patchy and infrequent." (p. 245) He finally had word from them in September 1941. "They had left Holland a month earlier with a small number of German Jews whom the Nazis had agreed to let leave, as a result of some complex negotiations and substantial financial sacrifices borne by the Warburg clan in New York." (p. 85). The family had fifty dollars with them upon arrival, en route to their "friend" Henry Behrens of 120 Cahrini Boulevard, New York City. 
In June of 1946, Mark got leave from the British Army. Ernest followed his father and uncles and the accidental military service of his brother when he himself entered military service on December 19th, 1944. The draft was in force, and Ernest's studies at Carnegie Institute of Technology had to wait when he reported to Camp Blanding in Florida.

Ernest's mother died on July 13, 1984 at 89 years. She lived in the US for 43 years. Arthur died on July 31 st 1962 at the age of 73 . He died 22 years before his wife. Ernest was 36 years of age when his father died and was 58 when his mother passed away. Both of his parents lived to see the lineage of teachers continue when Ernest took up his academic position at Rutgers in 1952.

Ernest did a one-year postdoctoral fellowship at Leiden University in Holland in 1951, returning to the place he grew from childhood to a young man. Dutch royalty had founded Leiden University in 1575, and it is one of Europe's leading research universities (https://www.universiteitleiden.nl/en/about-us). In 1952, he joined the physics department at Rutgers University in New York.

Ernest married his wife and colleague Carla in 1953. All of the people I spoke to for this issue were unanimous in their respect and admiration for Carla. This is where I learned how Ernest's work and their life together was often the same. They described Carla as Ernest's equal in all ways, but especially, if not more so, in intellect. Together, Carla and Ernest were extremely generous with their time and resources. They were benefactors of numerous charitable organizations and Carla was a long-time volunteer at the Perkins School for the Blind, where she received a lifetime achievement award for the number of volunteer hours she served. Carla contributed to causes from musical societies to Planned Parenthood to efforts to decrease elderly homelessness. Carla and Ernest were renowned for opening their home for faculty to gather and dialogue about societal and educational issues. Many talked about how these gatherings and the Lynton's generosity and care really made them feel like they mattered (Amy Driscoll, Lorilee Sandmam, Cathy Burack, Deb Hirsch, Personal Communication). Amy went on to say how "Ernest was the type of Provost a faculty member would want to work for." As we reflected on this together, we talked about how such generosity and openness to creating spaces for debate and dialogue was in opposition to the silos of the academy at the time. We agreed that Ernest modeled the values of co-creation and mutuality for which he advocated in his writings. While he was not always easy to work with, he respected colleagues and treated them as his equal. He made people believe that their ideas were just as important as his (Lorilee Sandmann, Amy Driscoll, Personal Communication).

\section{Ernest's Work: Out of the Discipline and Into the Urban University}

Ernest's early work within urban institutions influenced his commitments to diversity and access for underrepresented students, particularly young Black students. Through conversations with faculty from a diverse array of disciplines, Ernest learned the need for creativity and innovation in meeting the needs of students. Ernest experienced the limitations the traditional educational paradigm placed on faculty and students who wanted to teach and learn relevant curricula that would prepare students for their futures in the workplace and within society. These experiences presaged Ernest's exposure to the more practical and relevant purposes of higher education. Ernest recognized that universities, particularly metropolitan universities with a responsibility to 
its students and to nearby cities, needed to be more responsive to the lived experiences and needs of the changing times and students demographics.

Lynton believed that the goal of a liberal arts education is to create awareness of fundamental social, economic, and political problems and the manner in which the methodologies of relevant academic disciplines can address them. More specifically, Lynton cited the rapid, uncontrolled, and unbalanced growth of urban complexes, the explosive and often chaotic development of non-European nations, and the inability of Western countries to assimilate scientific and technical problems as areas around which the staff and curriculum of the new college might be organized. He proposed interdisciplinary majors relevant to each area, including urban studies, comparative literature, and programs in city and regional planning. (http://livingstonalumni.org/documentation)

\section{Livingston College: Great Expectations}

Ernest's time as the founding dean of Livingston College greatly influenced his commitment to the urban mission of higher education. Christopher Hann wrote a piece for Rutgers Magazine that conveys a strong sense of the time and the aspirations of the college. Livingston College came into being in 1965 and:

served as a living experiment in higher education, a quixotic attempt to provide a new academic experience for a new generation of students - more engaged, activist, even radical. It was, depending on your point of view, the hippie school, the black school, the utopian school, the anarchist school. "It was a campus," says Rob Snyder LC'77, "too easily defined by its extremes." As much as it was an actual place, Livingston was an idea - a whole set of brash, untested notions, really, burnished by the white-hot passions that fueled so much of the social upheaval across America in the 1960s. Central to Livingston's core was its commitment to students... who might otherwise never have access to a college education, including larger-than-ever numbers of minority, or, in the nomenclature of the college, nontraditional students. Livingston thus became the first coed liberal arts college at Rutgers with a special commitment to diversity, the first to create departments of Africana studies, Puerto Rican studies, women's studies, anthropology, community development, urban studies, and computer science... The founding dean, Ernest Lynton, a Yale-educated physicist who had taught at Rutgers College since 1952, had high expectations. Lynton wanted Livingston to become "the MIT of the social sciences"...Lynton's ability to recruit top-flight faculty was due largely to his ability to infect others with the passion he felt for the task at hand. (http://ucmweb.rutgers.edu/magazine/archive1013/features/spring-2012/greatexpectations) 


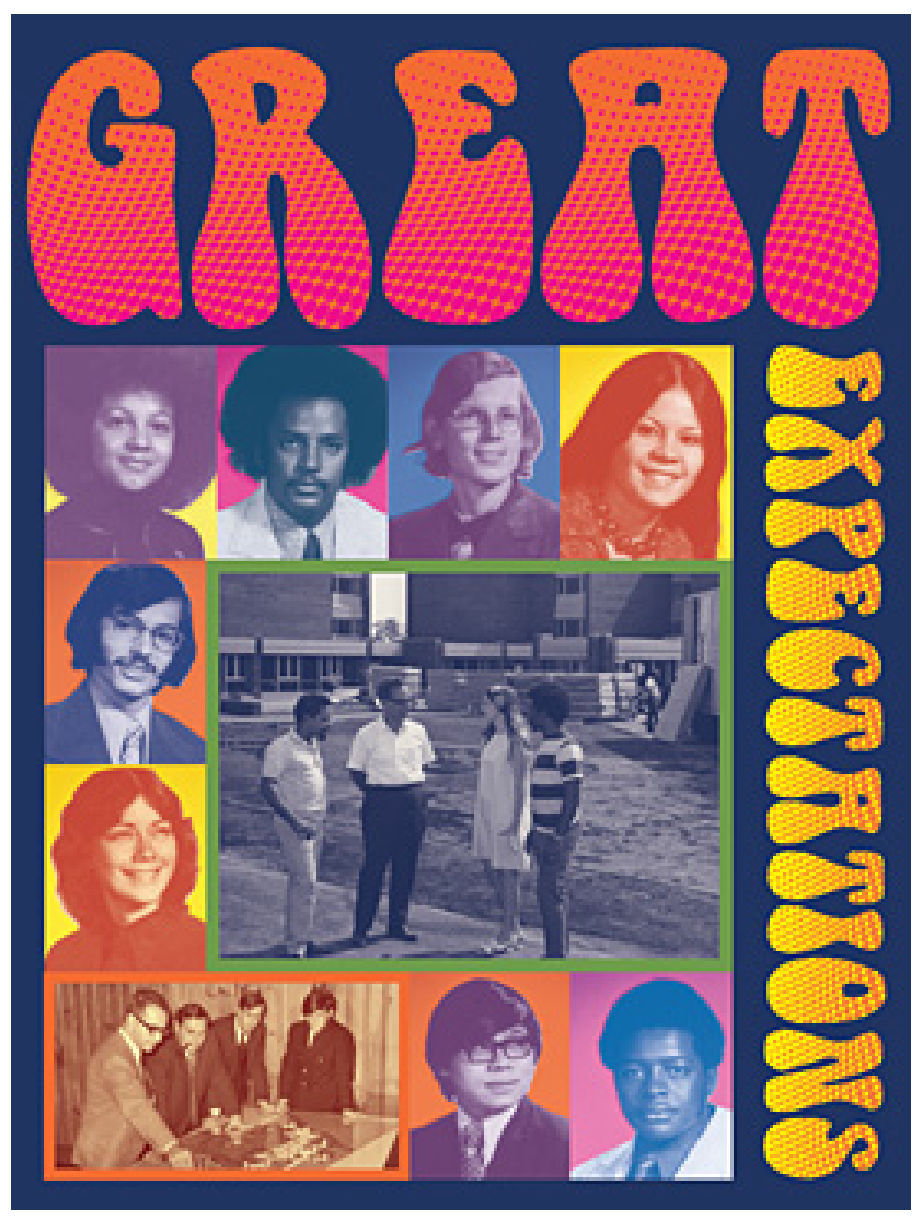

Figure 2. 1974 Livingston College Yearbook. Dean Ernest Lynton in dark glasses.

While Livingston began in 1965, the college did not open until 1969 with a freshmen class of 600 . The photo in the middle of the year book cover is of Ernest and students standing outside the resident halls with stacks of mattresses on barren ground. Livingston was opening for business, but the grounds were not quite ready. I discovered Ernest's commencement address to the first full graduating class of 500 Livingston College Seniors May 20, 1973. He declared:

We have shown, unmistakably that a College within a university can contribute to the highest levels of scholarship, research, and instruction of a university, while at the same time it can meet the educational needs of a broadly heterogeneous student body-the needs of black and Puerto Rican, the needs of the poor as well as the rich, the needs of the sons and daughters of working-class parents as much as those of the progeny of merchants and bankers - the needs as well of older and of part-time as much as those of younger, and full-time ones.

There are two common threads running through this multifaceted educational enterprise. One is a universal commitment to quality, and that is something which we have had to learn from each other slowly and sometimes painfully. It is only in an truly multiracial institution like ours that the white liberal can learn, from his black and Puerto Rican colleagues and critics, that the greatest arrogance of whites is their low expectation with 
regard to the performance of minority students - and gradually the lesson is being learned that the high expectations and demanding goals are what each of us owes to every one of our students.

And this common emphasis on quality makes possible the second common thread of our effort - the refusal to accept any track system of education in which students are channeled and boxed in according to their background. The most important feature of Livingston's fascinating educational mix is that it provides for all students the full range of opportunities - and encourages each to explore the very limits of his or her potential and aspirations, regardless of background and prior training. You who graduate here today have come from many different societal groups, many races and classes, many backgrounds. You go from here into a wide variety of occupations - further graduate and professional education, medical and law schools, jobs in private and public agencies, teaching and — inevitably_-some with no jobs at all. A great diversity — but the achievement of the College is that there is no correlation between where you are going and where you came from.

To be many things to many people, to provide a broad spectrum of education and career opportunities, to serve the needs of a heterogeneous student body — such achievements should, indeed must, be the ultimate aims of all colleges and all universities - but as yet Livingston stands nearly alone in this.

(Hidalgo, 1973, as cited in Livingston Alumni Association, 2017)

There is evidence of Ernest speaking of himself in this speech as the 'progeny of merchants and bankers' or the 'white liberal'. Former colleagues to whom I spoke for this article often mentioned Ernest's self-deprecating tendencies and the way he never shied away from making fun of himself. I find a level of honesty in this commencement speech that acknowledges his privileged background and yet commitment to diversity and access in higher education. The next vignette comes again directly from Ernest in another unpublished piece, and gives further insight into the origins of these commitments that later developed into the work of faculty roles and rewards for engaged scholarship, that we may be more familiar with. These are his own words as he reflected on his time at Livingston College. Here we see Ernest's growth from being an academic within the discipline to becoming an administrator and innovator in the larger urban university. His interest developed from others interested in higher education's responsiveness to student and workplace needs at the time. In 1965, Ernest related how he

met a growing number of people interested in higher education, and read and listened to what they had to say, that there was a need for fresh approaches and creative thinking regarding the role of universities and the nature of their pedagogy... So we set out to develop curricula that would be relevant to the student's social and personal concerns, and ways of teaching that would foster more individual initiative and provide greater flexibility...We were determined to treat our students as adults, able to make their own decisions without pervasive rules...In almost everything we instituted initially, we were ahead of the national trends... One of the most fascinating parts of my job in those formative years was to interview many people in the social sciences and humanities about 
what were the interesting directions in those fields, and who the most promising young people to recruited [as faculty]. That was especially the case in anthropology... Over a number of months in 1967 and 68 I went to see just about every leading anthropologist in the country - including Margaret Mead whom I visited in her eyrie under the eaves of the Museum of Natural History in New York. She and all the other luminaries were uniformly helpful and supportive, and there was much overlap in their recommendations both as to emerging fields as to hot young prospects... Out of conversations with individuals in other social science I obtained a strong sense of an impending shift in those fields toward an emphasis on complex social issues and public policy-particularly in the broad area of urban problems. And that became a central theme for Livingston: in sociology, political science, economics, (social) geography, we recruited individuals interested in urban issues and policies. (Lynton, 1996c).

Ernest's reflections here evidence the origins of his broadening beyond his own discipline of physics into the multidisciplinary landscape of that was to become Livingston college. One can begin to see where Ernest's conceptualization of an eco-system of knowledge creation began to emerge. Ernest emerged himself in such a transdisciplinary ecosystem as he sought to understand more fully the role of the university in a changing society. Ernest opened himself up to many different perspectives and ways of knowing as he sought 'fresh approaches and creative thinking' so he could develop curriculum and ways of teaching that were most relevant for the students Livingston wanted to enroll. Ernest sought out knowledge systems that are more "equipped to take the complexity of interrelationships" into account when the "dominant model of scientific knowledge [is more] characterized by reductionism and fragmentation" (Shiva, 2016 , p. 8). Ernest may have had the early realization that indigenous knowledge systems, being more wholistic, (Shiva, 2016) are often better suited to address 'complex urban social issues'. Ernest had great expectations for universities and hope to see a commitment to teaching and outreach instead of the "lopsided priorities" shifting institutional priorities and "excessive emphasis' toward research (Lynton, 1994b). Prior to my research for this issue, I wondered where the shift for Ernest was. How and why did he make the move from physicist to higher education reformer? As other's have indicated, Ernest was a product of his times (Saltmarsh, 2016; Rice, Personal Communication; Freeland, Personal Communication). Even still, it is nice to hear it from Ernest himself.

In 1973, Ernest left Rutgers and took up a position as the first system-wide vice-president for academic affairs. Here he penned the first comprehensive faculty personnel policy (Freeland, Personal Communication). In 1980, he left the vice-presidency and took a faculty position as the commonwealth professor for physics at the University of Massachusetts, Boston. However, Ernest did not leave his desire for higher education transformation far behind him. In 1988, with Zelda Gamson, Ernest co-founded the New England Resource Center for Higher Education (NERCHE). He focused his energies on advancing what he then called professional outreach. Over the next 10 years he worked with Cathy Burak, Deb Hirsch, Amy Driscoll, Lorilee Sandmann, and briefly Kerry Ann O'Meara on faculty roles and rewards and the documentation and promotional of professional outreach. This work laid solid foundation for the Carnegie Elective Classification for Community Engagement (Driscoll, Personal Communication) and the National Review Board for the Scholarship of Engagement (Sandmann, Personal 
Communication). While at the University of Massachusetts and NERCHE, Ernest's commitment to advancing the Urban and Metropolitan University became a core focus of his work.

\section{Coalition of Urban and Metropolitan Universities-Building an International Coalition}

The responsibility of the university in the sharing, pursuit, and application of knowledge ensures that our basic culture and heritage will be preserved. The university must guard its existence as an independent institution in order to achieve these primary functions. However, the university must not stand apart from its society and its immediate environment but must be an integral part of that society. The university best serves itself and society by assuming an active leadership role, as opposed to its traditional stance of somewhat passive responsiveness. (Hathaway, C.E., Mulhollan, P.E., and White, K.A., 1990)

With this mission in mind, Ernest and the founders of CUMU realized the collective responsibility required, not just of individual faculty members through their teaching and research, but of departments, collegiate units, and institutional leadership, as all work together to realize the 'complex and multidimensional mission of metropolitan universities (Lynton, 1996a; Lynton 1996b).

Ernest was concerned about both higher education's occupational (Lynton, 1983; Lynton, 1984; Lynton, 1989) and civic (Lynton, 1983; Lynton, 1996a; Lynton, 1996a; Lynton, 1995a) utility and effectiveness. He was also very much concerned with the "challenges of diversity" (Lynton, 1990a), the growing diversity of urban centers and therefore in student populations created a need for universities to respond to new student needs. Ernest's role as the founding dean of Rutger's Livingston College in 1965 and as the first system vice-president for academic affairs at the University of Massachusetts in 1973 led to his commitments to urban education.

Barbara Holland provides invaluable insight into Ernest's work in establishing CUMU and helping us understand more fully the intention behind the coalition.

Elaine: Tell me about your early work with Ernest and CUMU.

Barbara: Metropolitan universities are distinctive and it begins with a discussion with the challenge of responsibility and responsiveness to the scholarly and instructional needs of diverse cities and all of our institutions are really shaped by the fact that they are characterized by diversity, diversity of students, and diversity of scholarly and professional activities diversity of constituencies. From the very beginning we have been all about taking traditional scholarship and making it more responsive to a diverse world and by diversifying the ways we think about scholarship and who benefits from scholarship. Ernest had a strong commitment to diversity. The second issue of the journal was about student diversity, the third issue was about external needs and internal capacities, ways of communicating between the university and its regions, examining problems of intellectual interest and describing ways of involving students in a variety of outreach activities and the $4^{\text {th }}$ one was about faculty - the pedagogical challenges of a diverse student body, the professional challenges of what Ernest called outreach, the needs for 
new conceptions of scholarship, new criteria for promotion and tenure. Ernest was always ahead of his time. And he passed this on to me in so many ways.

Elaine: What do you recall about the early years of CUMU?

Barbara: Metropolitan Universities came together as an organization Chuck Hathaway and Paige Mulhollan. Wright State University held a meeting with several presidents. They felt that the metropolitan university had the characteristics of where higher education was going in the future. And for Ernest, this was all about diversity of students, diversity of teaching, learning by doing, and about changing faculty culture to help him that he truly believes that we have to figure out a way to recognize that scholarship is not just in the classroom or in the laboratory but also must be available and extended to the public. He was the father of CUMU and the first scholar to really articulate so long ago, in 1990, that where we were going is where we are today. He saw that the path forward for higher education in general was going to be the idea of scholarship that advances knowledge that is also shared and made accessible and involves partnerships with communities. And students had a role in this and that the connection to community would bring more diversity to our institutions.

Metropolitan universities are institutions of opportunity, focusing on the diversity of their cities and their student body and the necessity to have a diverse workforce and the necessity to create curriculum with experience. These concepts were "edgy and new in the 1990s."

It was Ernest who said we have to keep our work [advancing the metropolitan university] scholarly if we are going to have impact on higher education, which was their goal was to articulate what MUs understood about society and higher education. Ernest saw it had to be done through a scholarly process and that the journal would be the anchor of the strategy to identify and establish the characteristics of metropolitan universities and to draw in detail the case for why what MUs were doing at that time was foreshadowing what all universities are trying to do now. They first few issues of MU journal are what most universities are working on today diversity and equity, a curriculum that integrates experience, and diversity of faculty and staff, and the dual importance of research that contributes to the scholarly advancement and also contributes to public advancements. In the early 1990s these were not things everyone in higher education were talking about in the way we are today. There was concern about how to recruit and retain diverse students, but CUMU through the journal articulated this work in a way that was very compelling because it was based on already lived experience of living in urban space. Ernest was present for all of the first meetings of the coalition. The journal started after the first meeting and the journal serves as the glue of the organization in terms of learning and sharing from each other. That is the basis of the spirit you see at our conferences: very egalitarian and convivial, where students, college presidents, faculty and staff are all in the same room sharing together.

Elaine: Spirit of the work is coming through in the conversations with others, so not just the work or the reform that Ernest was trying to advance, but how he was doing it was importantinvolving others and being collaborative. 
Barbara: Yes. He had many mentees beyond me. Ernest and his wife were an incredible team and were involved in a number of charitable activities. They were personally involved in a variety of things to improve community development and cultural opportunities for all. He was an early exemplar of the engaged scholar as we call them today. Of someone who leads a scholarly life of inquiry and fact and evidence-based interpretation and he also lived in a world of "how do I use that for public good." And there was no difference between the two for him.

Elaine: His modeling of engagement is almost in opposition to the siloed nature and the isolation of higher ed. He created communities.

Barbara: Yes, he was not the solo scholar doing solo work for solo advancement.

Elaine: Which is a little ironic given the disciplinary background he comes from as a physicist.

Barbara: Absolutely. He's a hard core scientist.

Elaine: All the more reason to lift up the ways in which he did this work mirrors the values he had as an individual. The communities he helped create by opening his home.

Barbara: He certainly saw metropolitan universities as a medium for social justice, but he did it in a scholarly way, always understanding the public impact of this work. He used the journal early on to have the conversation about how we change promotion and tenure. How do we change our picture of our expectations of faculty work? He was the physicist who turned into a higher education scholar. How will we create a greater integration of teaching, research and service and research. How do we bring those together and not see them as separate. This was very edgy in the early 1990 s.

Elaine: Where do you think there was influence from or departure from Ernest Boyer?

Barbara: They have similar agendas in that higher education must change, it is changing and we need to magnify that rate of change, because it will make us a relevant contributor to society. Transformative day for the institution for the two Ernest's to be on campus and talking about change in higher education. Ernest Boyer had more in a political frame of mind, in the sense of foreseeing the loss of public appreciation and value of higher education and the need for us to think about new and different ways to demonstrate that value of what higher education contributes. Ernest Lynton would be more in the space of needing to look at public challenges and the diversity of our students and the equity of opportunity that higher education provides and how do we use our scholarship and our research and our teaching to create a more equitable society without diminishing in any way our academic rigor. Boyer may have been more of a political tactician and Ernest Lynton more of a coalition builder. They were two provocative voices. President Judith Ramaley's recollections of the day they were both on her campus are as follows:

In 1990, the Governor's Commission on the Future of Higher Education in Portland completed its deliberations and issued its final report calling for Portland State University to embrace the identity of an urban research university. That report opened up a new 
identity and sense of purpose for Portland State University. This all happened at a time when both Ernest Boyer and Ernest Lynton, each in his own distinctive way, were exploring and making sense of the changes that were beginning to take place in the relationships of colleges and universities to the broader society of which they are a part and the implications of those changes for the roles and responsibilities of faculty members. As PSU completed its new strategic plan in 1991 and began to embrace the urban mission that had for many years been embedded in its culture but not recognized or celebrated, it was clear that we were shifting our identity at a time when broad social, cultural, economic and political forces were creating a new context for higher education. There would be implications for our curriculum, our scholarly agenda and our working relationships and collaborations with other sectors of society.

To help us think through the significance of what it would mean to become an urban research university, we decided to invite some of the nation's most thoughtful observers and interpreters of higher education to join us, to think with us about what it would mean to become an urban-serving institution and to explore how we could express that mission. We invited two of the nation's most distinguished interpreters of higher education to join us to think about the path ahead.

Ernest Boyer had recently published two books that set the stage for our thinking. One was College. The Undergraduate Experience in America (1987) and the other was Scholarship Reconsidered, Priorities of the Professoriate (1990). Both were based on Boyer's extraordinary network of people and the conversations and ideas that he wove together so brilliantly to make the case for what soon became the model of an engaged university. He posed the question: "Can America's colleges and universities with all the richness of their resources, be of greater service to the nation and the world?" (Boyer 1990, p. 3).”

Ernest Lynton had already begun to explore the mission and purposes of metropolitan universities and played a pivotal role in establishing the Coalition of Urban and Metropolitan Universities and served as the founding editor of its journal. His passion for service and his deep understanding of the changing character of life in the $20^{\text {th }}$ century was an inspiration. In 1987, he and Susan Elman in New Priorities for the University described "the themes that would engage him for the remainder of his life---the role and responsibility of the 'metropolitan university' bringing to bear its resources to the knowledge needs of society, and the need to translate knowledge into understandable and usable forms (Hirsch, 2000 p. 57-58.)"

We brought both men to campus on the same day to talk with us about how our newly embraced mission as an urban research university could enable us to respond to the complex challenges facing society in an era of extraordinary social, political and technological change and all the consequences that these forces were exerting on the world around us. While their perspectives fit together like pieces of a jigsaw puzzle, neither alone would have offered us as rich and as meaningful a conversation by himself. Boyer was a grand synthesizer of conversations and ideas. Lynton was an astute observer of the forces reshaping our society and, in turn, the world order. Between them, they 
engaged us in deep reflection on how the world was changing and how we must change along with it. I only wish we had a transcript of that day. That conversation set the stage for our transformation into the university that Portland State is today. It is always one thing to be able to describe a desirable outcome. It is quite another to make that vision a reality. Ernest Lynton and Ernest Boyer got us off to a good start in inventing a very different approach to the core functions of a university in ways that have enabled us to achieve Lynton's goal of making "knowledge understandable and usable" while helping us expand our approach to scholarship to ensure that we would work with a broad range of community partners to address the questions that matter most in building healthy and resilient communities.

Judith A. Ramaley, President Emerita and Distinguished Professor of Public Service, Portland State University

This is a wonderful reflection on the influence of Ernest Lynton's work and impact in concert with the work of other thinkers in the field at the time.

Elaine: In what ways was Ernest being strategic in his thinking and practice?

Barbara: Ernest, from the beginning insisted that CUMU had a journal. Having the journal fully reviewed would add credibility and power to the idea to serve a more diverse student body, understand new forms of faculty work, change faculty culture and recognize that scholarship is both for scholars and for the public. Ernest knew that doing this in a scholarly way would give the organization a voice in working and collaborating with other organizations and starting to create a national movement around changing academic culture in a way that we now call giving credibility to community-engaged scholarship. NERCHE was a way to create a physical space to show the importance of developing collaborations between institutions. While some academic associations might be competitive, CUMU has always been about sharing and learning from each other. NERCHE was an on-the-ground, real example of his own institution, of how to bring people together around themes that were convened to share. Ernest's influence was his culture of openness and sharing and appreciating how we learn from one another, the conference emulates this as does the journal. And the role of NERCHE was his demonstration of what this looked like on the ground.

Elaine: Is this in opposition to the traditional paradigm?

Barbara: Exactly. The historic higher education paradigm was post-world war two and up until the late $80 \mathrm{~s}$ and $90 \mathrm{~s}$ was about competition. And there is still competition, but in the main the culture of academia today is much more collaborative and communicative then it has been. This is the way of the future. A number of institutions are starting to organize faculty around questions and problems and issues and topics and less about individual work. There is abundant evidence that institutions now are looking to be collaborative and the impact of engagement and the impact of the focus on more success for all students through more collaborative approaches to teaching and learning that help students succeed have changed everywhere. If we go back and look at the early issues of the journal in CUMU, we'll see that they were pressing this early on 
and it was one of the motivations for their own association was that they wanted to learn from each other.

\section{Ernest's Legacy}

Ernest has made many lasting contributions to metropolitan universities and their role and responsibilities in society. Of particular significance, his foundational work helped universities realize their mission through their recognition and reward of faculty community engaged teaching and research. The work he did with Amy Driscoll just before he died goes on through the Carnegie Elective Classification for Community Engagement. Many institutions across the country have revised their promotion and tenure guidelines in response to Ernest work. Lorliee Sandmann, Deb Hirsch, Barbara Holland, Cathy Burack, Kerry Ann O'Meara and Gene Rice were all (or became) leaders in advancing this work.

Ernest's legacy through the work of these women is of great significance. Often academic articles mention the names of others who worked with Ernest to advance the scholarship of engagement, Donald Schon, Gene Rice, Russ Edgerton, Lee Shulman, Ernest Boyer. I am happy to lift up the women involved in the early and subsequent waves of this work and hope that their names will begin to be acknowledged as widely. The contributions of Zee Gamsom, Amy Driscoll, Barbara Holland, Cathy Burack, Lorilee Sandmann, Deb Hirsch and Kerry Ann O'Meara merit our attention. I look forward to the next iteration of this work, that explores their contributions in more detail in turn lifting up their legacies.

My own approach to my work in higher education research involves attending to the process and the way we do our work. Ernest gives us lessons for how we engage in this work that is humble, lifting up of the other, not only respecting but also validating the contributions of all, whether graduate student, staff person, faculty member, administrator or colleague. Every contribution is as equally valid and legitimate as the other is. Ernest did not, according to the conversations I had with others, place more value on someone's contributions because they had positional leadership or authority. He gave as much time energy and space to the contributions of each one present. In relation to the hierarchy of higher education, he gave a platform and voice to graduate students as well as peers. I believe the Lynton award does just this: it validates and legitimizes the contributions of scholars whose work is having tremendous public impact but does not rate highly within the traditional paradigms of higher education. Through the external validation via the award, the legitimacy of that scholar's work by virtue of receiving the award is lifted up within their own institution.

Coming from the hard sciences, Ernest had legitimacy within those traditional, positivist paradigms. His humility, his intellectual openness and his commitment to making sure that the work that we do in higher education is of value to the professions, to businesses, to communities became his life's work. He wanted to make sure that the work that faculty did was recognized, validated, legitimized by policies and reward systems within the academy. How he engaged and moved this work forward was a role model for community-engaged scholarship. He modeled the values that drive our community-engaged scholarship, values of reciprocity, mutuality, respect for others, disrupting traditional knowledge hierarchies and epistemologies. He modeled those values in his work with junior scholars. 
Ernest did not claim that institutions should follow certain value systems or that he, in his position of privilege and power, should act and behave in another way. The values he demonstrated were the value systems driving the co-generation of knowledge, helping higher education have greater impact in in businesses or professions, the values that he said were essential to advance that work in authentic ways. Ernest's way of doing this work speaks to me through conversations with his closest colleagues, in ways that renew my commitment to how community engagement work can happen and should happen, the importance of processes that mirror the values that drive community-engaged scholarship. Therefore, as leaders and scholars, and thinkers in civic and community engagement, how are we living, modeling Ernest and Carla Lynton's legacy of inclusion, participation, epistemic equality, and not privileging one epistemological or methodological paradigm over another? How are we being inclusive and respectful in our own practices within higher education, with one another? How are we attending to the process and methods by which we do this work?

Lessons I have learned about Ernest's life behind the scholarship and publications has reinvigorated my commitment to these values. Ernest's partnership with his dear wife Carla, their opening up of their home, and the inclusive nature of their approach speaks to me and my commitment to finding ways that this work of advancing community engaged scholarship continues to attend to the processes by which we attempt to advance the work. How do we advance this work together? How do we validate one another? How do we legitimize the contributions of students, community partners, staff, and faculty of all ranks? How do we make space for the next generation of community engaged scholars and institutional change agents? How are we space makers in ways that we are helping the next generation attend to how we do the work, as much as what work is being done? How do we not perpetuate traditional, hierarchical paradigms? How do we advance value systems that are more respectful, collaborative, and lifting up of one another?

Ernest mentored and encouraged the next generation of institutional change agents through his work with Barbara, Amy, Lorliee, Deb, Cathy, and later Kerry Ann. In turn they have had great influence on me and the way I remember and attend to the value drivers in this work. The Lynton Award helps encourage recipients to attend to not only the 'what' of the work they are advancing, but the 'how' of that work. All this is part of Ernest's legacy. I hope to advance it further, by sharing this special issue with you all. Our responsibilities as individuals and colleagues are to be generous with our time, to be curious in our intellect, to be impatient with injustices, to want to change existing institutional paradigms and policies that promote epistemic injustice that devalue and delegitimize the work of some over others. 
Timeline: Ernest, Family and significant dates in German history

\begin{tabular}{|c|c|c|}
\hline Year & Date & Loewenstein Family \\
\hline 1769 & & $\begin{array}{l}\text { Loew Lippmann Loewenstein born (Ernest's great, great } \\
\text { grandfather) Teacher ISteinback near Schwaebisch Hall. } \\
\text { Ernest's great, great grandmother was Ester (daughter of } \\
\text { Abraham Moyses Simon Rimon and Kela in Oettingen - Ernest's } \\
\text { great, great, great grandparents) }\end{array}$ \\
\hline 1850 & & Ernest's great, great grandfather, Loew, dies. \\
\hline 1852 & Oct 26 & $\begin{array}{l}\text { Naphtali Loewenstein, Ernest's grandfather - born in Oedheim, } \\
\text { works as a banker in Stuttgart. }\end{array}$ \\
\hline 1863 & May 26 & $\begin{array}{l}\text { Emilie Wormser, Ernest's paternal grandmother, born in } \\
\text { Aldingen, near Stuttgart. }\end{array}$ \\
\hline 1895 & Jun 28 & Martha Luise Kiefe (Ernest's mother) born near Stuttgart. \\
\hline 1889 & Aug & Arthur Jakob (Ernest's father born, Stuttgart, Germany) \\
\hline 1912 & & Arthur publishes a book on banking (possibly his doctoral thesis) \\
\hline 1920 & April 16 & Ernest's brother, Max-Otto Ludwig Loewenstein, is born. \\
\hline 1922 & & $\begin{array}{l}\text { Arthur named head of a major German car manufacturer. } \\
\text { Loewenstein family moves from Stuttgart to Berlin }\end{array}$ \\
\hline 1923 & Aug 5 & Naphatali (Ernest's grandfather) dies in Stuttgart. \\
\hline 1923 & & Hitler goes to prison after the failed "Beer Hall Putsch." \\
\hline 1924 & May 16 & Emilie (Ernest's grandmother) dies in Stuttgart. \\
\hline 1924 & & Hitler is released from prison, gains popular support. \\
\hline 1926 & July 17 & Ernest is born in Charlottenburg, Berlin, Germany \\
\hline 1933 & & Hitler and Nazi party win election and attain full power. \\
\hline 1933 & & Mark, age 13, goes to school in France. Ernest is six years old. \\
\hline 1935 & & Nuremberg laws strip rights from Jews. \\
\hline 1935 & & Ernest is nine. His family leaves Berlin for Amsterdam. \\
\hline 1936 & & Mark goes to Cheltenham, England. Ernest is ten years old. \\
\hline 1938 & Nov 9 & Kristallnacht_-beginning of the Holocaust \\
\hline 1939 & & German invasions of Poland. The Second World War begins. \\
\hline 1940 & May 10 & Germany invades the Netherlands. \\
\hline 1941 & August & Ernest's family evacuate to Lisbon on the steamship Mouzinho. \\
\hline 1941 & Sept 2 & Ernest's family arrive at Ellis Island. \\
\hline 1941 & & Ernest and his parents reside in New York, New York. \\
\hline 1943 & & One year of college Carnegie Institute of Technology. \\
\hline
\end{tabular}




\begin{tabular}{|l|l|l|}
\hline Year & Date & Ernest Lynton \\
\hline 1944 & Dec 19 & Enlists for U.S. military service as a private. \\
\hline 1945 & Feb 20 & Petitions for naturalization while stationed in Florida. \\
\hline 1945 & Sept 2 & World War II ends. \\
\hline 1946 & & Brother Max, now Mark Lynton, rejoins family in New York. \\
\hline 1951 & & $\begin{array}{l}\text { Earns a doctorate in physics from Yale. } \\
\text { Postdoctoral fellowship in Leiden University, Amsterdam. }\end{array}$ \\
\hline 1952 & & Joins the Physics Department at Rutgers. \\
\hline 1953 & & Marries Carla Kaufmann in New York City. \\
\hline 1962 & & Authors Superconductivity. \\
\hline 1962 & & His father Arthur dies in New York City. \\
\hline 1964 & & Founding Dean of Livingston College, Rutgers. \\
\hline 1969 & & Livingston College opens to 500 students. \\
\hline 1973 & & Senior VP for Academic Affairs, University of Massachusetts. \\
\hline 1980 & & Commonwealth Professor of Physics, U. of Massachusetts. \\
\hline 1982 & & Publishes Corporate Education: College Opportunity. \\
\hline 1983 & & Joins the John McCormack Institute for Public Affairs. \\
\hline 1983 & & $\begin{array}{l}\text { Publishes A Crisis of Purpose: Reexamining the Role of the } \\
\text { University, and The Economic Impact of Higher Education. }\end{array}$ \\
\hline 1984 & & His mother Martha dies in New York City. \\
\hline 1984 & & $\begin{array}{l}\text { Authors The Missing Connection Between Business and the } \\
\text { Universities. }\end{array}$ \\
\hline 1984 & March & $\begin{array}{l}\text { Presents The Post-Industrial University: New Structures for New } \\
\text { Missions at the National Conference on Higher Education }\end{array}$ \\
\hline 1987 & & Authors with Sandra Elman New Priorities for the University. \\
\hline 1988 & & $\begin{array}{l}\text { Co-founds The New England Resource Center, with Zelda } \\
\text { Gamson. }\end{array}$ \\
\hline 1989 & & Founding of Coalition of Urban \& Metropolitan Universities. \\
\hline 1990 & & First editor of Metropolitan Universities journal. \\
\hline 1994 & & Authors Knowledge and Scholarship. \\
\hline 1995 & & Retires as Editor of Metropolitan Universities Journal \\
\hline 1996 & Dies in Brookline, MA. Laid to rest in Wakefield, MA. \\
\hline 1998 & $\begin{array}{l}\text { Publication of Making outreach visible, co-authored with Amy } \\
\text { Driscoll. }\end{array}$ \\
\hline 1999 & &
\end{tabular}




\section{References}

Boyer, E. L. (1987) College. The Undergraduate Experience in America. New York. Harper and Row Publishers.

Boyer, E. L. (1990) Scholarship Reconsidered. Princeton: The Carnegie Foundation for the Advancement of Teaching.

Driscoll, A. \& Lynton, E.A. (1999). Making outreach visible: A guide to documenting professional service and outreach. ED 441392. Washington, DC: American Association for Higher Education (AAHE). Retrieved from https://files.eric.ed.gov/fulltext/ED441392.pdf

Hann, C. (2012 Spring). Great expectations. Rutgers Magazine. Retrieved from http://ucmweb.rutgers.edu/magazine/archive1013/features/spring-2012/great-expectations

Hidalgo, H. (1973). No one model American: A collegiate case in point. The Journal of Teacher Education, 24 (4), 294-301. As cited in Livingston Alumni Association. (2017). Early History: 1960s and 1970s. Retrieved from http://livingstonalumni.org/early-history-1960s-and-1970s

Hirsch, D. (2000) Ernest Lynton Remembered. Journal of Higher Education Outreach and Engagement, 6 (1), 57-59. Retrieved from

http://openjournals.libs.uga.edu/index.php/jheoe/article/view/237

Hathaway, C. E., Mulhollan, P. E., \& White, K. A. (1990 Spring). Metropolitan Universities: Models for the Twenty-First Century. Metropolitan Universities, 1 (1), 9-20. Retrieved from https://journals.iupui.edu/index.php/muj/article/view/19023

Lynton, E. A. \& Sandra E. Elman. (1987). New Priorities for the University: Meeting Society's Needs for Applied Knowledge and Competent Individuals. San Francisco: Jossey-Bass.

Lynton, E. A. (1996a). Ensuring the quality of outreach: The critical role of evaluating individual and collective initiatives and performance. Journal of Public Service and Outreach, 1(2), 16-22.

Lynton, E. A. (1995a). Making the Case for Professional Service, Washington D.C: American Association for Higher Education (AAHE).)

Lynton, E. A. (1996b). Reversing the Telescope: Viewing Individual Activities within a Collective Context. Metropolitan Universities, 7 (3), 41-45. Retrieved from https://journals.iupui.edu/index.php/muj/article/view/19571

Lynton, E. A., (1996c). From Berlin to Brookline. Unpublished.

Lynton, E. A. (1983 October). A Crisis of Purpose: Reexamining the Role of the University. Change, 15 (7), 18-23. https://doi.org/10.1080/00091383.1983.10570016 
Lynton, E. A. (1984). The missing connection between business and the universities. American Council on Education/Macmillan Series on Higher Education. New York: Macmillan Publishing Co.

Lynton, E.A. (1989). Higher education and American competitiveness. Working paper series: The federal role in education. New York: National Center on Education and the Economy.

Lynton E.A. \& Elman, S. E. (1987). New priorities for the university. San Francisco, California: Jossey-Bass Inc.

Lynton, E. A. (1991) From the Editor's Desk. Metropolitan Universities, 2 (2), 2-3. Retrieved from https://journals.iupui.edu/index.php/muj/article/view/19198

Lynton, E. A. (1994a Summer). Knowledge and Scholarship. Metropolitan Universities, 5 (1), 917. Retrieved from https://journals.iupui.edu/index.php/muj/article/view/19385

Lynton, E. A. (1994b). The changing nature of universities. New England Journal of Public Policy, 10 (1), 241-250. Retrieved from https://scholarworks.umb.edu/nejpp/vol10/iss1/21/

Lynton, M. (1995). Accidental journey: A Cambridge internee's memoir of World War II. Woodstock, NY: Overlook Publishers.

Saltmarsh, J., Ward, E., \& Clayton, P. (2011). Profiles of public engagement: Findings from the Ernest A. Lynton Award for the Scholarship of Engagement for Early Career Faculty. NERCHE Report. New England Resource Center for Higher Education, University of Massachusetts, Boston.

Ward, E. (2010). Women's ways of engagement: An exploration of gender, the scholarship of engagement and institutional reward policy and practice. Doctoral Dissertation. University of Massachusetts, Boston.

Shiva, V. (2016), Biopiracy: The plunder of nature and knowledge. Berkeley, CA: North Atlantic Books.

Saltmarsh, J. (2016). Ernest Lynton and the tyranny of research. Journal of Higher Education Outreach and Engagement, 20 (1), 45-52. Retrieved from https://files.eric.ed.gov/fulltext/EJ1097205.pdf 


\section{Author Information}

Elaine Ward, Ed.D.

Merrimack College

315 Turnpike Street

North Andover, MA 01845

Telephone: (978) 837-3572

Email: warde@merrimack.edu

For almost ten years, Dr. Ward has worked with faculty nominees and recipients of the Ernest A. Lynton Award for the Scholarship of Engagement for Early Career Faculty, served as the award coordinator and has chaired and co-chaired the Annual Lynton Colloquium. Dr. Ward writes and teaches on the institutionalization of civic and community engagement within higher education as is co-editor of the book Publicly Engaged Scholars: Next Generation Engagement and the Future of Higher Education (2016). Dr. Ward was also one of the leads on the international pilot of the Carnegie Elective Community Engagement Classification in Ireland. Dr. Ward has served on the board of the International Association for Research on Service Learning and Community Engagement and was the conference program chair in 2016, Reaffirming Our Purpose, Bridging Our Understandings \& Broadening Our Collective Impact. Currently, Dr. Ward is an Assistant Professor of Higher Education at Merrimack College, School of Education and Social Policy. 